\title{
Embedded Verb Second (V2)
}

\author{
Kristine Bentzen \\ UiT The Arctic University of Norway
}

\section{Introduction}

The Mainland Scandinavian languages (MSc) are all Verb Second (V2) languages, typically displaying movement of the finite verb to the second position of the clause in main clauses, (1a-b). In contrast, embedded clauses are generally assumed to not show this kind of verb movement, (1c) (cf. among many others Holmberg and Platzack 1995, Vikner 1995):

(1) a. Han leste ikke avisen
he read not paper.the today

'He didn't read the newspaper today.'

b. Idag leste han ikke avisen.

today read he not paper.the

'Today he didn't read the newspaper.'

c. Visste $\mathrm{du}$ at han ikke leste avisen idag?

knew you that he not read paper.the today

'Did you know that he didn't read the newspaper today?'

However, as is also well-known, this is not the full picture. Already Holmberg and Platzack (1995) and Vikner (1995) (again among many others) demonstrated that certain embedded contexts allow verb movement, both across negation, yielding subject-initial V2 with the word order $V$-Neg, as in (2a), and across the subject, yielding non-subject initial V2 with the word order $X P-V-S$, as in (2b):

(2)
Hun sa...
(Norwegian)
she said

a. at han leste ikke avisen idag.

that he read not paper.the today

'She said that he didn't read the paper today.' 

b. at idag leste han ikke avisen.
that today read he not paper.the

'She said that today he didn't read the paper.'

Embedded V2 has been tested across MSc for that-clauses embedded under various types of predicates. The results in the Nordic Syntax Database are presented below.

\section{Results}

\subsection{Nordic Syntax Database (NSD)}

\section{Asserted complements}

For embedded V2 with verb movement across negation ( $\mathrm{V}$-Neg) in asserted complements embedded under predicates like say, the following sentences were tested in Danish, Norwegian, and Swedish:

(3) Han mente at hun havde ikke set den film før. (\#146) (Danish)

he meant that she had not seen that film before

'He meant that she hadn't seen that film before.'

(4) Han sa at han kunne ikke synge denne sangen i bryllupet.

(Norwegian)

he said that he could not sing this song.the in wedding.the

'He said that he couldn't sing this song at the wedding.'

This word order is widely accepted in asserted complements all over Norway, Sweden, and Finland. It is also accepted on Eastern Jutland in Denmark. However, in the rest of Denmark, this word order is typically rejected. Furthermore, we also find rejections of this word order at scattered places in (mostly) Southern Norway and a few places in Sweden. This is shown in Map 1: 


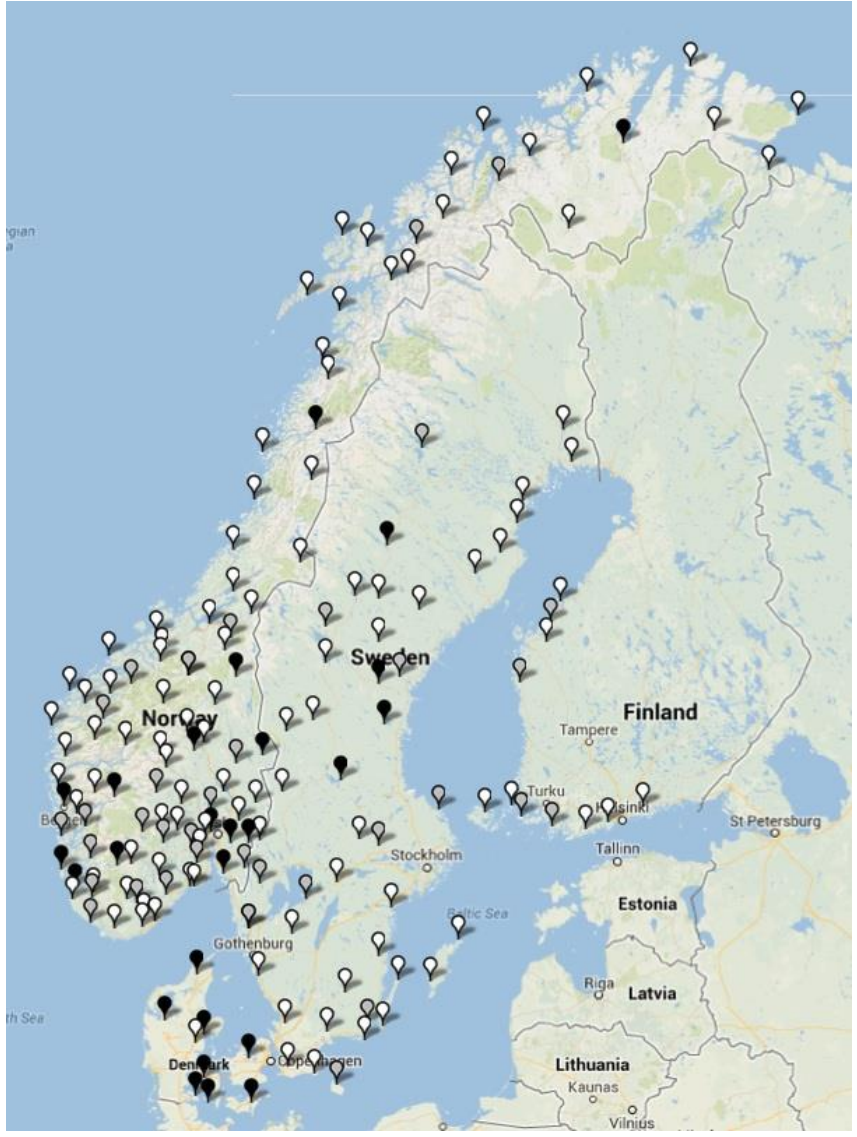

Map 1: Judgments of V-Neg in asserted complements

(\#146: Han sa han kunne ikke synge denne sangen i bryllupet. 'He said he couldn't sing this song at the wedding.')

$($ White $=$ high score $;$ grey $=$ medium score $;$ black $=$ low score $)$

For embedded V2 with verb movement across the subject $(X P-V-S)$ in asserted complements, the following sentences were tested in Norwegian, Swedish, and Icelandic:

(5) Han sa at denne sangen kunne han ikke synge i bryllupet.

he said that this song.the could he not sing in wedding.the

'He said that this song he couldn't sing at the wedding.'

This word order is accepted in asserted complements all over Norway (except in Røros), Sweden, and Finland (except Dragsfjärd). It is also accepted in various places in Iceland, although it mostly receives a medium score here (and is rejected in Vestmannaeyjar). 


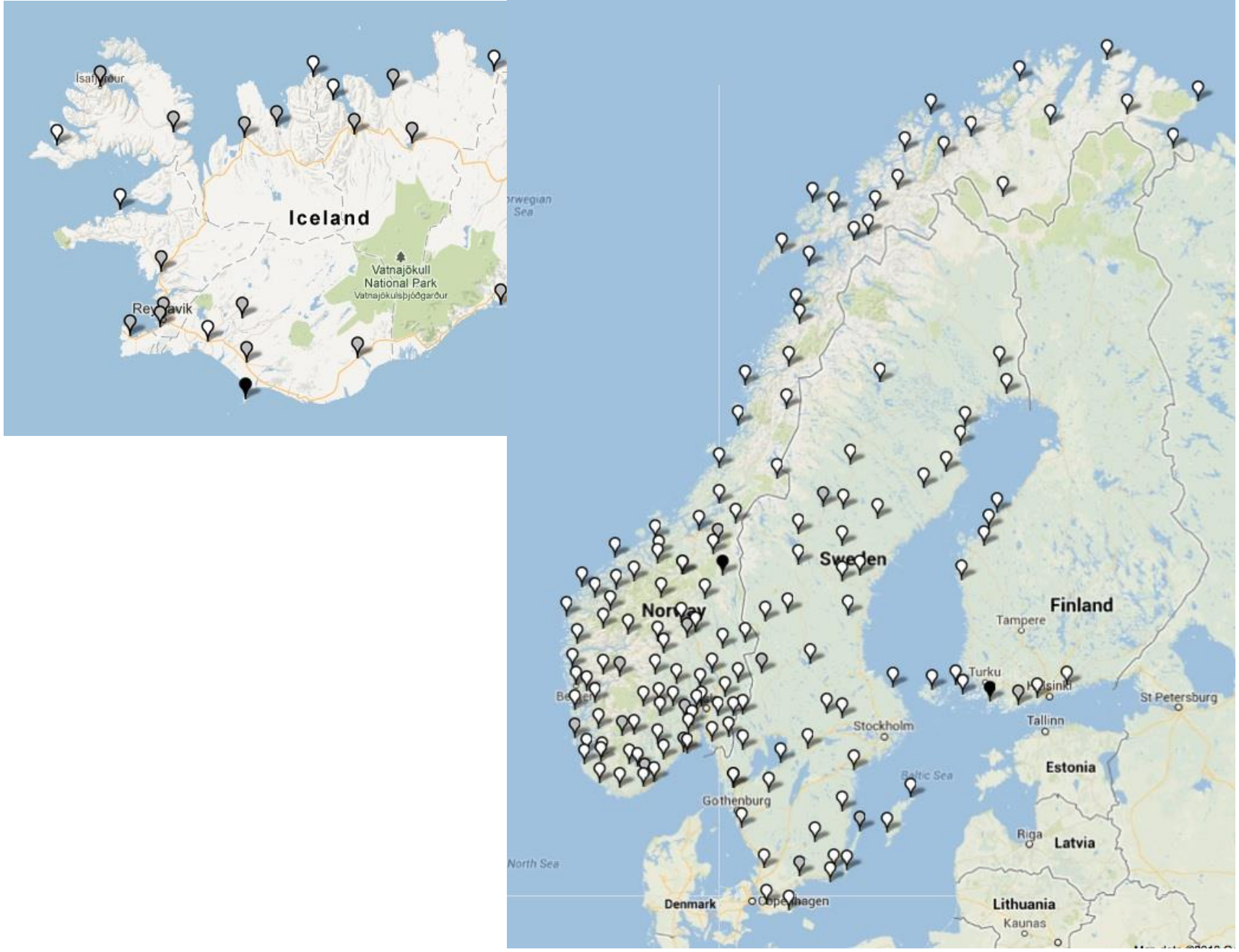

Map 2: Judgments of XP-V-S in asserted complements

(\#147: Han sa at denne sangen kunne han ikke synge i bryllupet. 'He said that this song he couldn't sing at the wedding.')

$($ White $=$ high score $;$ grey $=$ medium score $;$ black $=$ low score $)$

\section{Semi-factive complements}

For embedded V2 with verb movement across negation ( $V$-Neg) in semi-factive complements embedded under a predicate like discover, the following sentences were tested in Danish, Norwegian, and Swedish:

(6) Jeg oppdaget at jeg hadde ikke lest denne boka før.

\section{I discovered that I had not read this book.the before}

'I discovered that I hadn't read this book before.'

The word order $V$-Neg is accepted in semi-factive complements all over Sweden and Finland, and in most areas in Norway. However, we do find rejections of this word order in semi-factive complements several 
places in Norway (mostly the southern part and in Finnmark) and a few places in Sweden. In Denmark, on the other hand, this word order is consistently rejected:

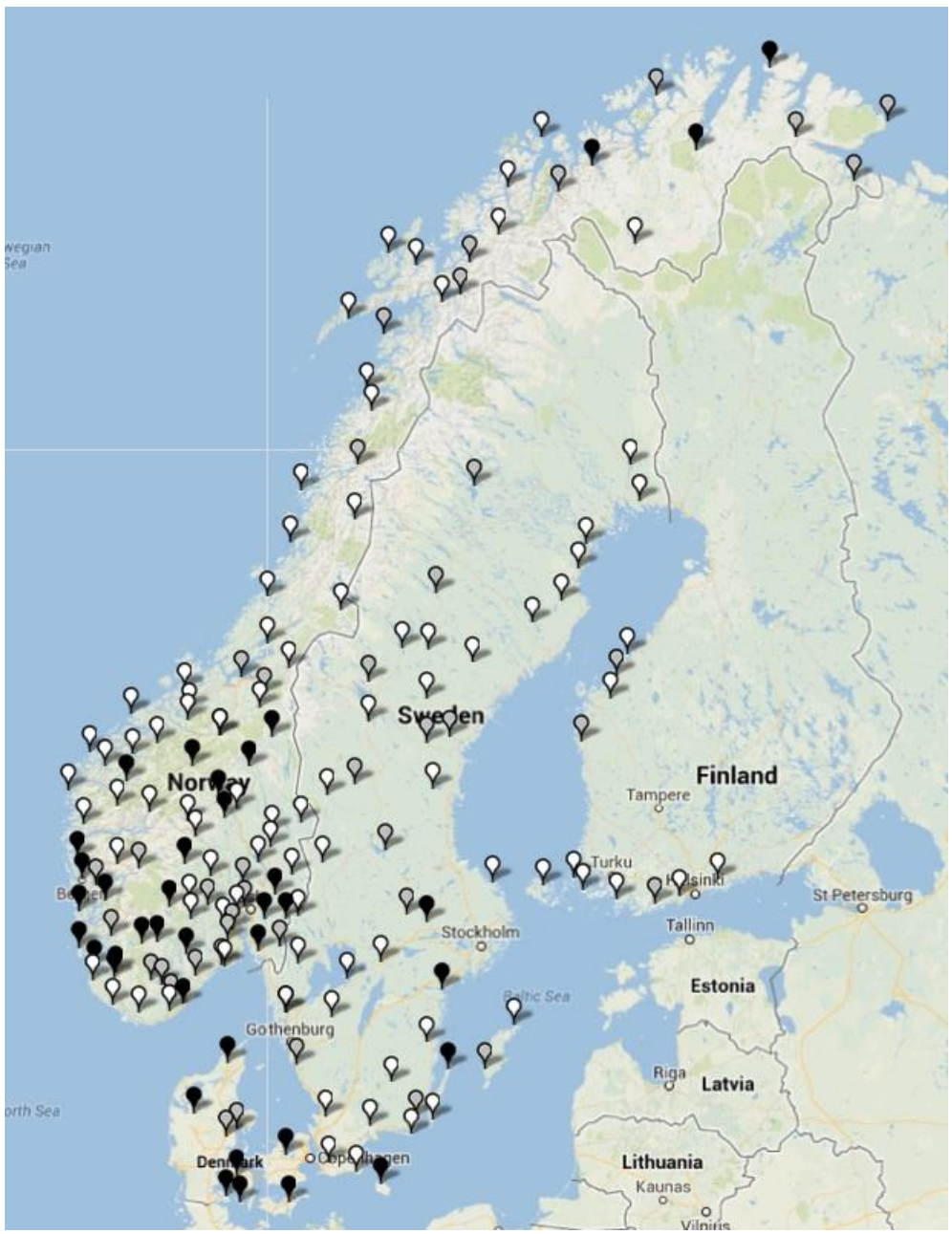

Map 3: Judgments of $V$-Neg in semi-factive complements

(\#154: Jeg oppdaget at jeg hadde ikke lest denne boka før. 'I discovered that I hadn't read this book before.')

$($ White $=$ high score $;$ grey $=$ medium score $;$ black $=$ low score $)$

For embedded V2 with verb movement across the subject $(X P-V-S)$ in semi-factive complements, the following sentences were tested in Norwegian, Swedish, and Icelandic:

(7) Jeg oppdaget at denne boka hadde jeg ikke lest før.

I discovered that this book.the had I not read before

'I discovered that this book, I hadn't read before.'

This word order is accepted in semi-factive complements more or less all over Norway, Sweden, Finland, and Iceland (although only marginally so, with medium scores, in certain locations in Norway, Sweden, 
and Finland). In Norway, we find rejections in Røros and in a few places in the Southern part of the country: Fredrikstad, Darbu, Hjelmeland, and Karmøy.

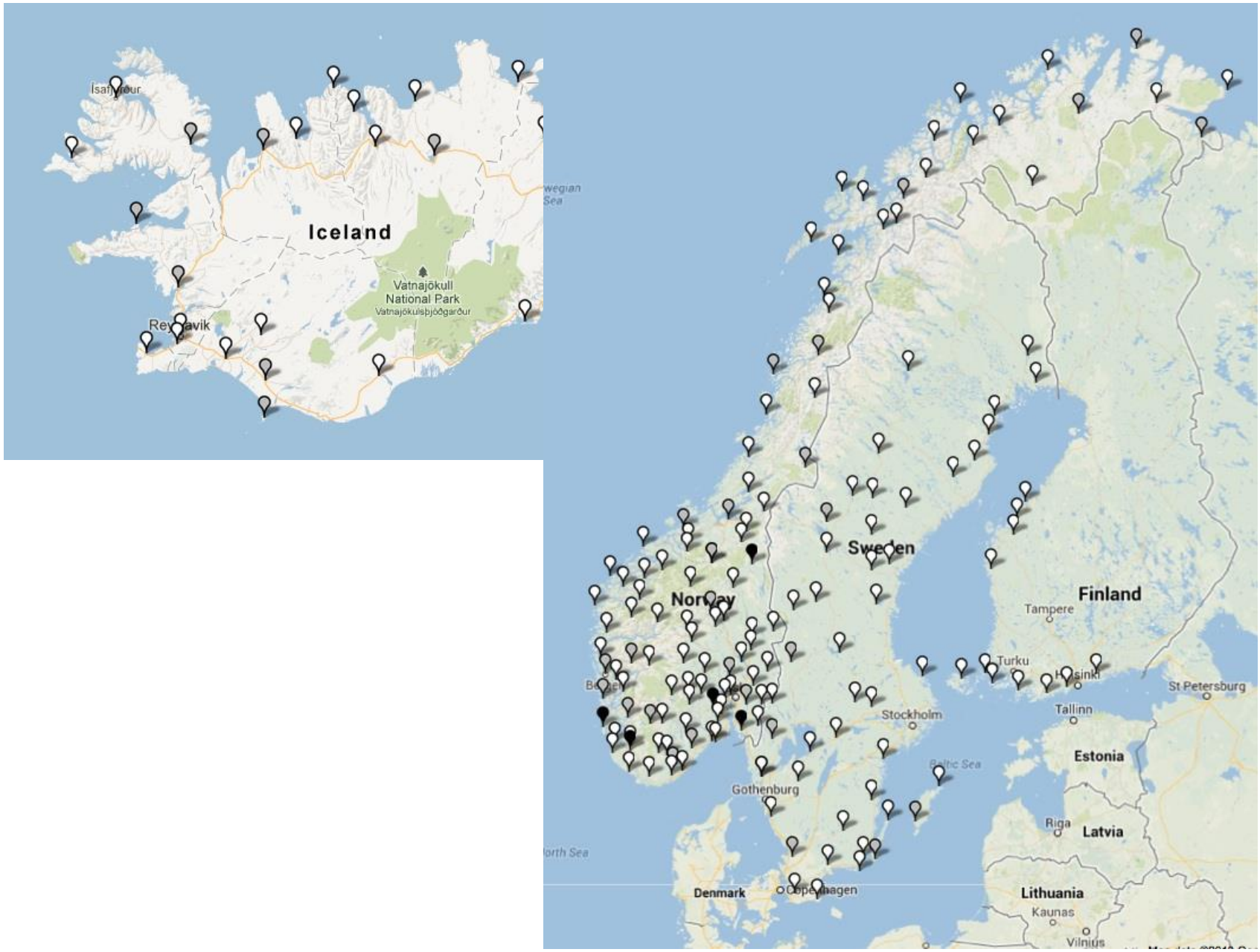

Map 4: Judgments of XP-V-S in semi-factive complements

(\#155: Jeg oppdaget at denne boka hadde jeg ikke lest før. 'I discovered that this book, I hadn't read before.')

$($ White $=$ high score $;$ grey $=$ medium score $;$ black $=$ low score $)$

\section{Non-asserted complements}

For embedded V2 with verb movement across negation ( $\mathrm{V}-\mathrm{Neg})$ in non-asserted complements embedded under predicate like doubt, the following sentences were tested in Danish, Norwegian, and Swedish:

(8) Han tviler på at hun har ikke møtt denne mannen før.

(Norwegian)

he doubts on that she has not met this man.the before

'He doubts that she has not met this man before.'

This word order is typically rejected in Denmark, Norway, and Sweden. However, it is accepted in certain places across Norway, Sweden, and in Finland (Norway: Kirkesdalen, Ballangen, Herøy (in 
Nordland county), Inderøy, Aure, Rauma, Volda, Kalvåg, Hyllestad, Luster, Tinn; Sweden: Överkalix, Kalix, Vindeln, Anundsjö, Indal, Särna, Bengtsfors, Orust, Floby, Fårö; Finland: Larsmo, Munsala, Dragsfjärd, Snappertuna, and Kyrkslätt).

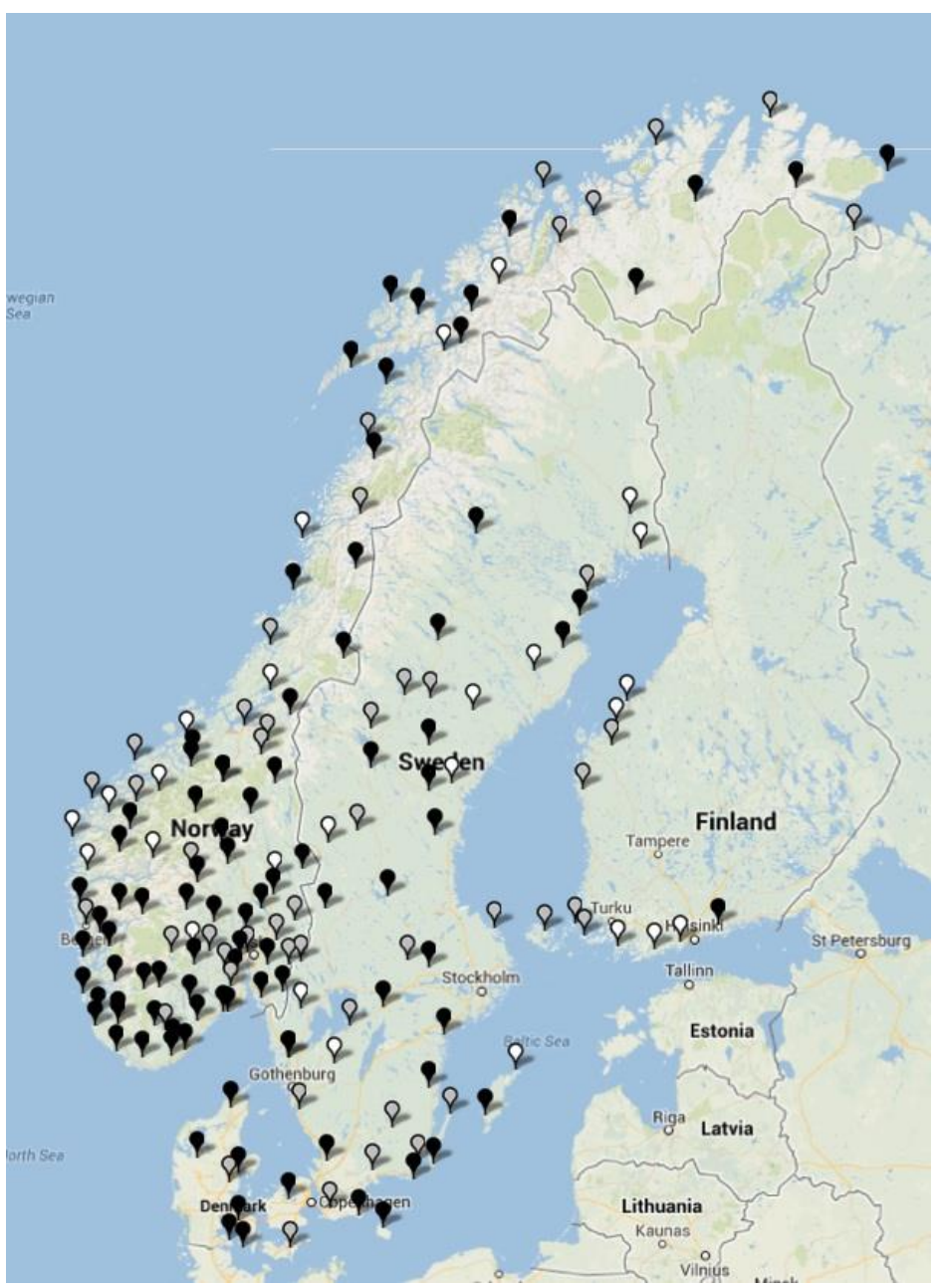

Map 5: Judgments of V-Neg in non-asserted complements

(\#150: Han tviler på at hun har ikke møtt denne mannen før. 'He doubts that she has not met this man before.')

$($ White $=$ high score $;$ grey $=$ medium score $;$ black $=$ low score $)$

For embedded V2 with verb movement across the subject $(X P-V-S)$ in non-asserted complements, the following sentences were tested in Norwegian, Swedish, and Icelandic:

(9) Han tviler på at denne mannen har hun ikke møtt før.

he doubts on that this man.the has she not met before

'He doubts that she has met this man before.'

In Finland and Sweden this word order is generally rejected; it is accepted only in a few places (Brändö in Finland, and Ovanåker, Ankarsrum, and Gräsö in Sweden). In Norway the word order is accepted and 
rejected all across the country. In Iceland the word order is mostly accepted in the North-East and in the South-West, and typically receives a medium score in the North-West and in the South-East.

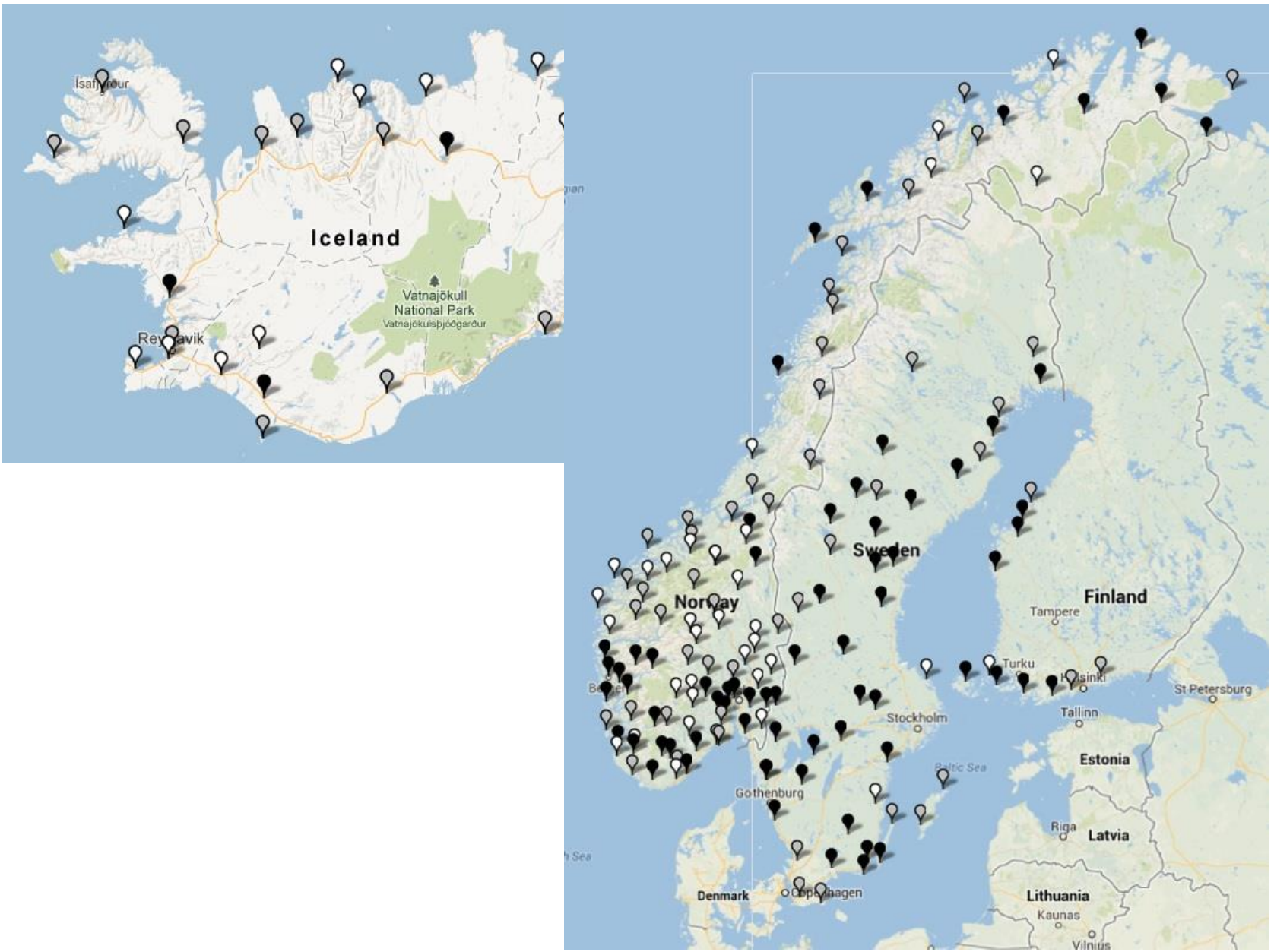

Map 6: Judgments of XP-V-S in non-asserted complements

(\#1391: Han tviler på at denne mannen har hun ikke møtt før 'He doubts that she has met this man before.')

$($ White $=$ high score $;$ grey $=$ medium score $;$ black $=$ low score $)$

\section{Factive complements}

For embedded V2 with verb movement across negation ( $\mathrm{V}-\mathrm{Neg}$ ) in factive complements embedded under predicate like regret, the following sentences were tested in Danish, Norwegian, Swedish, and Icelandic:

(10) Han angra på at han hadde ikke lest denne avisen.

(Norwegian)

he regretted on that he had not read this paper.the

'He regretted that he hadn't read this newspaper.' 
(11) Han fortrød at han havde ikke sunget den her sang. (\#152) (Danish)

he regretted that he had not sung this here song

'He regretted that he hadn't sung this song.'

This word order is generally rejected across Denmark, Norway, and Sweden. However, it is accepted in a few places in Norway (Herøy (in Nordland county), Namdalen, Gauldal, Oppdal, Volda, Hyllestad, Vang, Stange, Darbu, and Vinje). Moreover it is accepted in one location in Sweden (Byske) and two locations in Finland (Larsmo and Dragsfjärd), and otherwise receives several medium scores in Finland. In Iceland this word order is frequently accepted or given a medium score, but it is rejected a few places (Pingeyjarsveit, Dalvík, Stykkishólmur, Borgarnes, and Reykjavík):

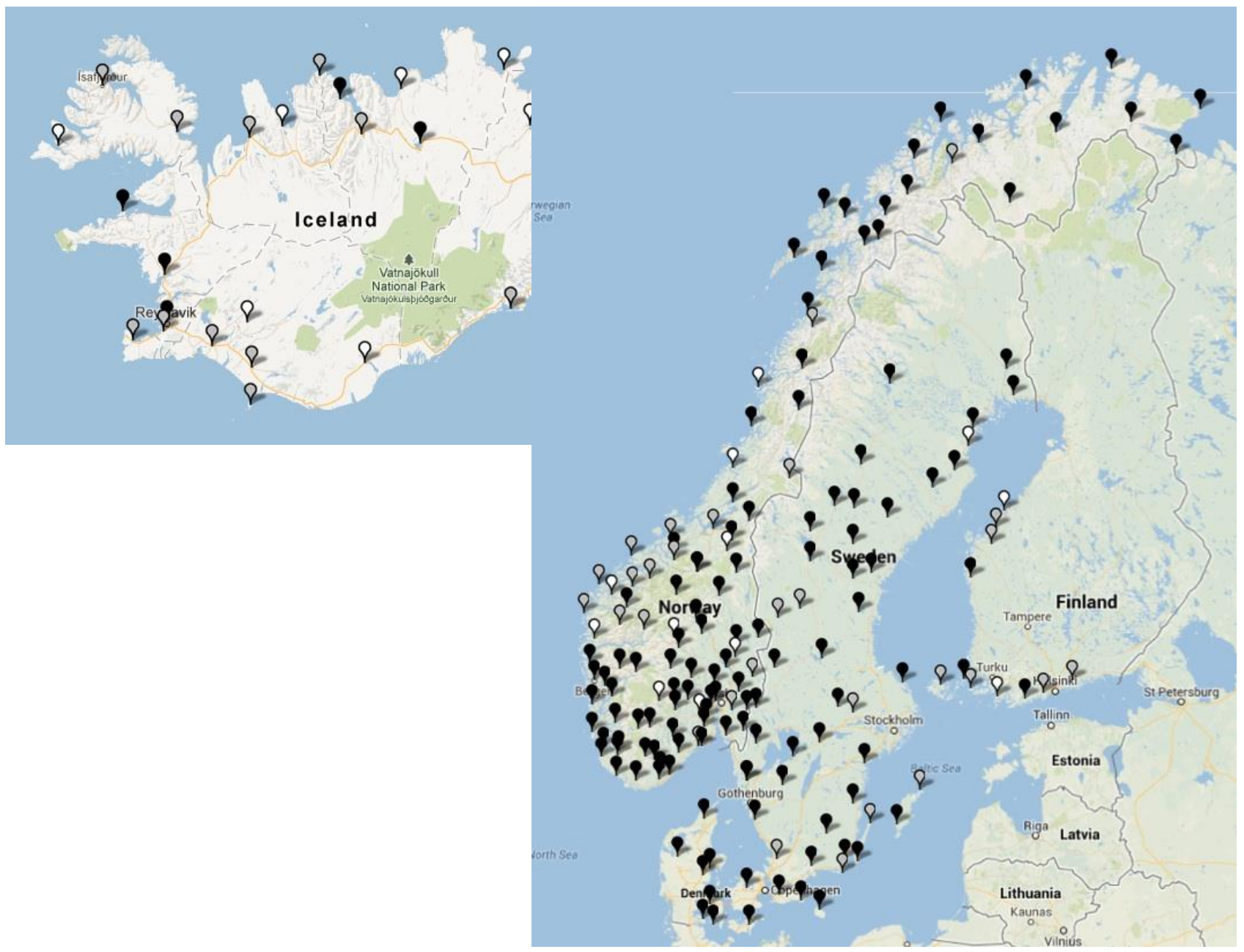

Map 7: Judgments of V-Neg in factive complements

(\#152: Han angra på at han hadde ikke lest denne avisen. 'He regretted that he hadn't read this newspaper.')

$($ White $=$ high score $;$ grey $=$ medium score $;$ black $=$ low score $)$

For embedded V2 with verb movement across the subject $(X P-V-S)$ in factive complements, the following sentence was tested in Norwegian, Swedish, and Icelandic: 
(12) Han angra på at denne avisen hadde han ikke lest.

he regretted on that this paper.the had she not read

'He regretted that he hadn't read this newspaper.'

(13) Leifur sá eftir að pað lag hafði hann ekki sungið í veislunni.

(Icelandic)

Leifur saw after that that song had he not sung in party.the

Leifur regretted that he hadn't sung that song at the party.'

This word order is both accepted and rejected in factive complements all over Norway and Sweden. In Finland it is mostly accepted or given a medium score; only in Vörå is this word order rejected. In Iceland it is always rejected (or given a medium score): 


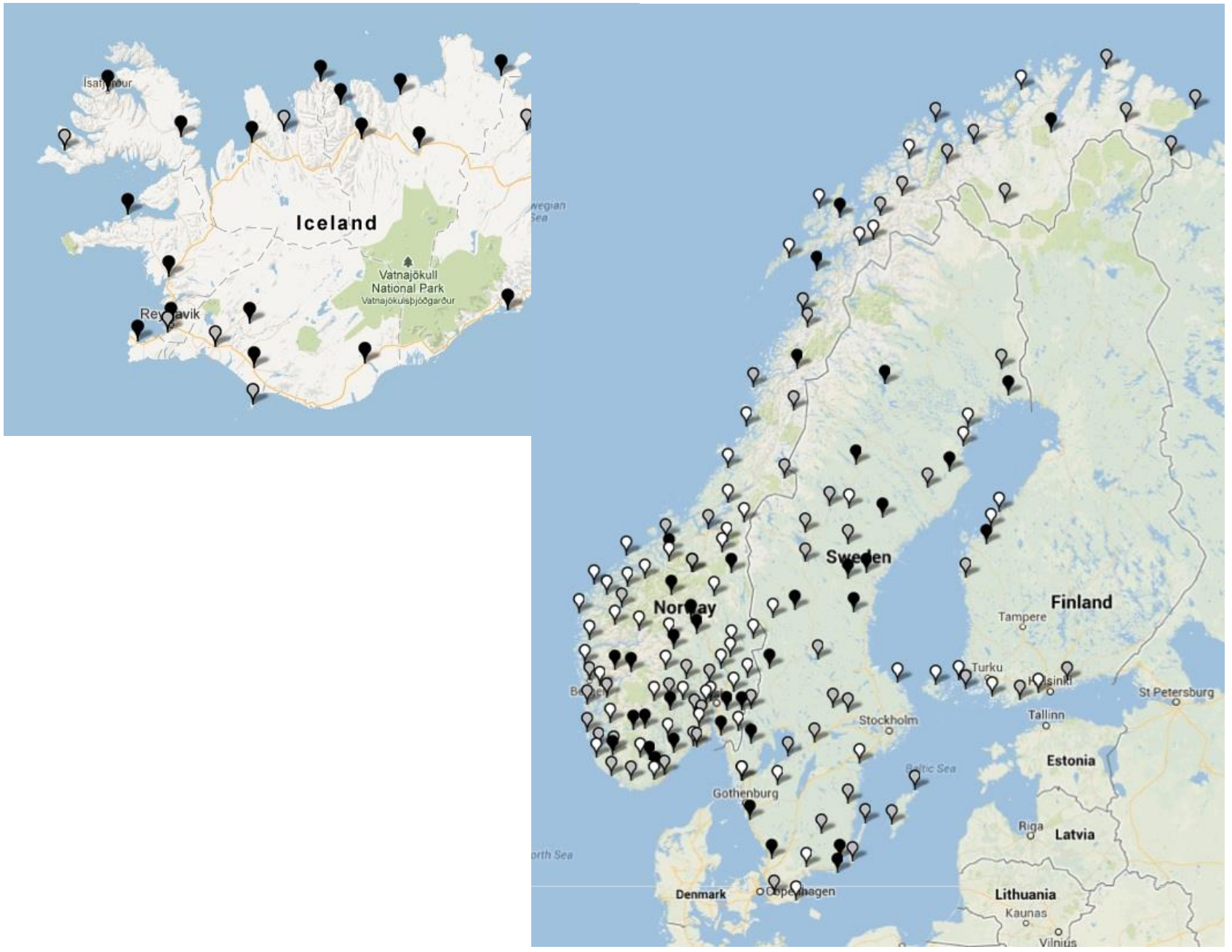

Map 8: Judgments of XP-V-S in factive complements

(\#153: Han angra på at denne avisen hadde han ikke lest. 'He regretted that he hadn't read this newspaper.')

$($ White $=$ high score $;$ grey $=$ medium score $;$ black $=$ low score $)$

Summing up, the data from the Nordic Syntax Database first of all suggest that embedded V2 in Danish is generally rejected (note that only subject-initial V2 ( $\mathrm{V}$-Neg) was tested in Danish). In contrast, we find that both subject-initial V2 $(V-N e g)$ and non-subject initial V2 $(X P-V-S)$ are freely available in that-clauses embedded under assertive and semi-factive predicates in Norwegian, Swedish, and Icelandic (note that only the word order $X P-V-S$ was tested for Icelandic embedded clauses of this type). Moreover, the results show that non-subject initial V2 $(X P-V-S)$ is quite frequently accepted here and there across Norway, Sweden, and Finland in complements embedded under factive predicates, but typically rejected in Iceland. Finally this word order is also accepted in non-asserted complements here and there in Norwegian, and consistently so in Iceland.

Differences related to age groups were investigated, but not found to be significant. 


\section{Discussion}

As mentioned in the introduction, the availability of embedded V2 has been discussed extensively in the literature on Scandinavian syntax (cf. among many others Andersson 1975, Rögnvaldsson \& Thráinsson 1990, Holmberg \& Platzack 1995, Vikner 1995, Heycock 2006, Thráinsson 2007, Brandtler 2008, Petersson 2009). These works have pointed out that even though V2 is typically rejected in subordinate clauses in MSc, certain that-clauses still do allow word orders $V$-Neg and $X P-V-S$. In the seminal work by Vikner (1995), the proposed generalization was that complements of so-called bridge verbs (verbs allowing extraction from their complements) could display V2 type of word orders. Focusing on English, Hooper and Thompson (1973) proposed a correlation between the availability of embedded root phenomena (e.g. argument fronting, locative inversion, tag question formation) and the types of predicates a given clause is embedded under. More specifically, they showed that asserted and semifactive embedded clauses typically allow embedded root phenomena, whereas non-asserted and factive complement clauses do not (cf. also Haegeman 2006).

In some of the more recent work, Julien (2007, 2009) and Wiklund et al. (2009) (but see also Andersson 1975) have discussed the phenomenon of Scandinavian embedded V2 in relation to the more general availability of embedded root phenomena in languages like English. Looking at Mainland Scandinavian, both Julien (2006, 2007) and Wiklund et al. (2009) in general found that the environment for embedded $\mathrm{V} 2$ in these languages corresponds with the environment for other embedded root phenomena. Wiklund et al. (2009) argue that Icelandic also follows this pattern with respect to embedded non-subject topicalization. The word order $\mathrm{V}$-Neg in Icelandic is generally assumed to involve verb movement that is independent of $\mathrm{V} 2$, and thus, this word order is not taken to be an indication of embedded V2 in Icelandic. However, non-subject topicalization followed by subject-verb inversion, is assumed to be an instantiation of V2 also in Icelandic. Thus, the proposal in Wiklund et al. (2009) is that the restrictions on embedded V2 across the Scandinavian languages (in the shape of $V$-Neg and XP-V-S in Mainland Scandinavian and of $X P-V-S$ in Icelandic) are the same (contra Rögnvaldsson \& Thráinsson 1990 and Vikner 1995).

In light of claims in the previous literature, the results from the Danish part of the Nordic Syntax Database are somewhat surprising. As the above section indicates, the word order $V$-Neg (which is the only embedded V2 word order tested in Danish) is generally rejected in all kinds of that-clauses in Danish. This finding is also surprising given the reports by Christensen and Jensen (2011) and Jensen (2011), which suggest that in spontaneous speech, Danish indeed allows word order $V$-Neg in many types of embedded clauses, including that-clauses.

Turning to Norwegian and Swedish, the data from the Nordic Syntax Database confirm the observations made by Julien and Wiklund et al., namely that embedded V2 is freely available in asserted and semi-factive embedded clauses in Norwegian and Swedish. This holds for both $V$-Neg and XP-V-S. Along the lines of the claims made in Julien and Wiklund et al, we also see that subject-initial V2 ( $V$ $\mathrm{Neg}$ ) is generally rejected in factive and non-asserted complement clauses. However, non-subject initial V2 $(X P-V-S)$ is quite frequently accepted in such clauses (for non-asserted complements, especially in 
Norwegian). This diverges from the claims made in Wiklund et al. Notably, we see that even in asserted and semi-factive complements, embedded V2 word orders are sometimes rejected, and here too, word order $V$-Neg is more often rejected than $X P-V-S$. This suggests that the word order $X P-V-S$ in general is more easily available in that-clauses than word order $V$-Neg.

Moreover, for non-subject initial V2, there seems to be a hierarchy in the acceptability of this word order among the four different types of that-clauses in Norwegian and Swedish:

Hierarchy of acceptability of word order XP-V-S

asserted $>$ semi-factive factive $>$ non-asserted

$X P-V-S$ is always accepted in asserted complements, and only rejected in five places in semi-factive complements. The word order is accepted much less often in factive complements, but all locations allowing this word order in factive clauses, also allow it in semi-factive complements. Furthermore, $X P$ $V-S$ is even less accepted in non-asserted complements, but all locations allowing this word order in such complements also allow it in factive complements.

With respect to the word order $\mathrm{V}$-Neg, we do not see such a hierarchical relationship in Norwegian and Swedish: this word order is typically accepted in asserted and semi-factive complements (though slightly more often rejected in semi-factive complements), and it is typically rejected in non-asserted and factive complements (about equally often, though not always in the same locations).

Finally, for Icelandic, the data from the Nordic Syntax Database only partially support for the claim in Wiklund et al. (2009). In asserted and semi-factive complements, non-subject initial V2 $(X P-V-S)$ is indeed frequently accepted in Icelandic. Interestingly, however, proportionately, we find more medium scores in these contexts in Iceland than we do in Norway, Sweden, and Finland. Moreover, the results from the factive complements also resemble the situation argued for in Wiklund et al., in that non-subject initial V2 appears to be mostly rejected in these clause types. However, in contrast with Wiklund et al.'s findings, the Nordic Syntax Database shows that non-subject initial V2 is also fairly often accepted (or given a medium score) in non-asserted complements. Moreover, the results for the factive complements are somewhat questionable in that even the word order $V$-Neg is sometimes rejected here, and quite often receives a medium score. This is surprising given that $V$-Neg should be the default word order in Icelandic embedded clauses, and suggests that the high rejection rate of both the $V$-Neg and the $X P-V-S$ word orders might be rejected for reasons not having to do with the word order as such. The matrix predicate used for 'regret' in this investigation is sá eftir. This was deliberately chosen over the predicate harma with a similar meaning, as harma has been argued to sometimes behave more like a semi-factive than a factive predicate (cf. Thráinsson 2007, Wiklund et al. 2009). However, it is possible that the speakers somehow find the predicate sá eftir less natural, and that this could have led to the rather high rejection rate of this sentence in general. 


\section{References}

Andersson, Lars-Gunnar. 1975. Form and function of subordinate clauses. Ph.D. thesis, Gothenburg University.

Brandtler, Johan. 2008. 'On the structure of Swedish subordinate clauses,' Working Papers in Scandinavian Syntax 81, 79-97.

Christensen, Tanya Karoli and Torben Juel Jensen. 2011. 'Language use data meet categorical theory the case of word order in Danish subordinate clauses,' talk given at the $2^{\text {nd }}$ N'CLAV Grand Meeting, Gottskär, Sweden.

Haegeman, Liliane. 2006. 'Argument fronting in English, Romance CLLD and the left periphery,' in Raffaella Zanuttini, Héctor Campos, Elena Herburger, Paul Portner (eds.) Negation, Tense and Clausal Architecture: Cross-Linguistic Investigations. Georgetown University Press, Washington, DC, 27-52.

Heycock, Caroline. 2006. 'Embedded root phenomena,' in Martin Everaert and Henk van Riemsdijk (eds.) The Blackwell Companion to Syntax, vol. II. Blackwell, Oxford, 174-209.

Holmberg, Anders and Christer Platzack. 1995. The Role of Inflection in Scandinavian Syntax. Oxford University Press, New York.

Hooper, Joan and Sandra Thompson. 1973. 'On the applicability of root transformations,' Linguistic Inquiry 4, 465-497.

Jensen, Torben Juel. 2011. 'Ordstilling i ledsætninger i moderne dansk talesprog,' Ny forskning $i$ grammatik 18, 123-150.

Julien, Marit. 2007. 'Embedded V2 in Norwegian and Swedish,' Working Papers in Scandinavian Syntax $80,103-161$.

Julien, Marit. 2009. 'The force of the argument,' Working Papers in Scandinavian Syntax 84, 225-232.

Petersson, David. 2009. 'Embedded V2 does not exist in Swedish,' Working Papers in Scandinavian Syntax 84, 101-149.

Rögnvaldsson, Eirikur and Höskuldur Thráinsson. 1990. 'On Icelandic word order once more,' in Joan Maling (ed.) Syntax and Semantics: Modern Icelandic Syntax, vol. 24. Academic Press, San Diego, $3-40$.

Thráinsson, Höskuldur. 2007. The Syntax of Icelandic. Cambridge University Press, Cambridge.

Vikner, Sten. 1995. Verb Movement and Expletive Subjects in the Germanic Languages. Oxford University Press, New York.

Wiklund, Anna-Lena, Kristine Bentzen, Gunnar Hrafn Hrafnbjargarson, and Thorbjörg Hróarsdóttir. 2009. 'On the distribution and illocution of V2 in Scandinavian that-clauses,' Lingua 119.12, 19141938.

\section{Web sites:}

Nordic Atlas of Language Structures (NALS) Journal: http://www.tekstlab.uio.no/nals

Nordic Dialect Corpus: http://www.tekstlab.uio.no/nota/scandiasyn/index.html

Nordic Syntax Database: http://www.tekstlab.uio.no/nota/scandiasyn/index.html 